\title{
Characterization of Village Chicken Production and Breeding Practices of Smallholders in Eastern Ethiopia
}

\section{Bruh Asmelash ${ }^{*}$, Mahlet Dawit and Ewonetu Kebede}

School of Animal and Range Sciences, College of Agriculture and Environmental Sciences, Haramaya University, Ethiopia

"Corresponding author: Bruh Asmelash, School of Animal and Range Sciences, College of Agriculture and Environmental Sciences, Haramaya University, Ethiopia, Tel: +251-933236506; E-mail: bruhasmelash@yahoo.com

Rec date: December 26, 2017; Acc date: January 18, 2018; Pub date: January 19, 2018

Copyright: (c) 2018 Asmelash B, et al. This is an open-access article distributed under the terms of the Creative Commons Attribution License, which permits unrestricted use, distribution, and reproduction in any medium, provided the original author and source are credited.

\begin{abstract}
The study was conducted in Eastern Ethiopian districts of Oromia regional State such as Meta, Deder, Goro Gutu, Babile, and Jigjiga districts of Somali regional state. So far in Eastern Ethiopia, very little effort has been made in characterization of village chicken production, husbandry and identification of smallholder's trait selections. Therefore, this study was initiated with the aim of characterization of village chicken production, husbandry, breeding practices and identification of smallholder's trait selection in Eastern Ethiopia. Majority (42.29\%) of respondents maintained large proportion of layers in the flock in the study area. The village chicken production of the study districts were characterized by poor management which used scavenging system as major feed resources (99\%), no appropriate house $(93.3 \%)$, no regular vaccination $(100 \%)$ and uncontrolled breeding. The mean annual egg production of the village chicken of the districts was estimated at 51.66 in an average of 3.69 production cycles a year. All smallholders in the study area keep chickens principally for cash income more important than egg and meat production for home consumption. Moreover, majority of respondents get benefit $(31.74 \%)$ from chicken manure through application as a fertilizer for garden vegetable production in their backwards. The respondents $(89 \%)$ confirmed that "Fengil" (New castle disease), "Albasa" (Coccidiosis) and "Kinkin" (External parasites) are the serious disease outbreak results in complete devastation of the flock. Most stallholders ranked first the egg size birds laying $(0.412)$ and second reproduction performances $(0.276)$ among their selection criteria's. Only few respondents $(35 \%)$ reared their own cock for a breeding purpose and majority had no breeding experience in improving their chicken productivity.
\end{abstract}

Keywords: Chicken; Production; Smallholders; Respondents

\section{Introduction}

A review by Gueye indicated that nearly $80 \%$ of the estimated 1.3 billion chickens in Africa comprise indigenous breeds raised by village farmers under extensive systems. Most chicken in Ethiopia are indigenous (49.3 million), distributed across different agro-ecological zones and mostly under a traditional family-based scavenging management system [1,2]. This indicates that they are highly important farm animals kept as a good source of animal protein and income to most of the rural populations [3]. Furthermore, their widespread distribution indicates their adaptive potential to the local environmental conditions, diseases and other stresses [4]. In Ethiopia, the indigenous chicken contributes to more than $90 \%$ of the national chicken meat and egg output [5]. Although, the chicken has a significant contribution to the national economy, production per chicken is extremely low [3]. Moreover, Nigussie et al. characterized village chicken production by small size of unimproved indigenous flock per household, birds maintained under scavenging regimens in the backyards with little or no supplemental feeding, no separate shelters except for night enclosures in the family house, and lack of health care [5]. However; the plan to increase the productivity of this indigenous chicken at village system by using exotic breeds in Ethiopia failed to become a sustainable option mainly because this strategy recurrently faced the problem of birds not being adopted widely by the rural farmers due to several socioeconomic and environmental challenges. Moreover, indigenous chickens are preferred to exotic chickens because of their pigmentation, taste, flavor and leanness [6]. Among the indigenous chicken ecotypes, farmers also traditionally choice for traits describing the adaptive attributes, genetic merits, production potential, and consumer's preference in the market. Therefore; understanding smallholder's breed preference for chicken enables researchers to develop appropriate selection criteria and breeding programs to maintain chickens with the most preferred trait for village conditions. However, so far in Eastern Ethiopia, very little effort has been made characterization of village chicken production, husbandry and identification of smallholder's trait preference for chicken ecotypes before genetic improvement made by utilization of both selection and crossbreeding. This is among the problems Teklewold et al. reported that increased the productivity of indigenous chicken at village system by using exotic breeds in Ethiopia failed to become a sustainable option. Therefore, this study was initiated with the aim of identifying and characterization of village chicken production, husbandry and breeding practices of smallholder chicken producers in Eastern Ethiopia.

\section{Materials and Methods}

\section{Description of the study area}

The study was conducted in eastern Hararghe districts of Oromia regional State; namely, Meta, Deder, Goro Gutu, Babile, and Jigjiga districts of Somali regional state. The study districts Meta, Deder, Goro Gutu, Babile and Jigjiga are located at about 435, 430,408, 557 and 621 $\mathrm{Km}$ east of the capital city of Addis Ababa, respectively. The average 
rainfalls of the districts are 750,900, 850,605 and $606 \mathrm{~mm}$, whereas the mean annual temperature of Meta, Deder, Goro Gutu, Babile, and Jigjiga are $20,21.5,29,26$ and $18^{\circ} \mathrm{C}$, respectively. The study districts were selected based on their chicken production potential and accessibility to Haramaya University where investigators are working. Among the chicken producers of smallholders a total of 60 households (20 per each district) were randomly selected for the study and interviewed through questionnaire about the chicken production and management, purpose of keeping chickens, trait preferences, and production constraints, breeding practice and selection criteria. The chicken production and management data were analyzed by index system and descriptive statistics in SAS.

\section{Results and Discussion}

\section{Characterization of chicken production and management practices in the study area}

Flock structure and characteristics: Flock structure is described in terms of proportion of the different sex and age groups in the flock. In the study area majority $(42.29 \%)$ of respondents maintaining large proportion of layers (Table 1). The higher proportion of layers in the flocks is an indication of strong desire for egg and chick production $[7,8]$. The relatively large proportion of layers in all study districts might purposively do by the farmers' to increase egg production either to securing the sources of replacement flocks or selling eggs to generate income when need is raise. The lower proportion of the spent birds within the indigenous chicken population might be attributed to the culling or replacing breeding chickens at appropriate age. Cockerels and cocks are maintained in a flock for breeding and sharing of cocks among neighbors is a breeding strategy in a community.

\begin{tabular}{|l|l|l|l|l|l|l|}
\hline \multirow{2}{*}{ Age group } & \multicolumn{5}{|c|}{ Districts (\%) } & \multirow{2}{*}{ Average } \\
\cline { 2 - 7 } & Meta & Deder & Gursum & Babbile & Jigjiga & \\
\hline Layer & 57.69 & 47.06 & 32.17 & 48 & 26.53 & 42.29 \\
\hline Cocks & 11.5 & 7.84 & 20.89 & 14.67 & 16.33 & 14.23 \\
\hline Pullet & 15.38 & 19.6 & 15.65 & 10.67 & 16.33 & 15.53 \\
\hline Chicks & 15.38 & 25.5 & 21.74 & 26.67 & 26.53 & 23.16 \\
\hline $\begin{array}{l}\text { Spent } \\
\text { chickens }\end{array}$ & - & - & 9.57 & & 14.29 & 4.77 \\
\hline
\end{tabular}

Table 1: Flock structure by age, sex and production.

Feed resources and feeding practices: The major feed resources in the study districts were scavenging system, which accounts $99 \%$. Few respondents practiced insufficient and infrequent supplementary feeding of home available cereal grains such as maize, wheat and kitchen left over during the morning. The result of this study was in disagreement to that of Asefa and Mekonnen who reported 95-98\% of the small scale household poultry producers in Awassa Zuria and Dale offer supplementary feeding to their chickens. All the available evidences tend to indicate that scavenging feed resource base for local birds are inadequate and variable depending on season [2].

Housing system: About $93.3 \%$ of the respondents reported to have no separate poultry house (Table 2). Among the households who have no separate poultry houses, the respondents indicated that their birds perch in the kitchen, under bed and at one corner in the house.
Housing facilities in the surveyed area include the use of hand woven basket and bamboo cages placed on the bare floor or slat floor in the family house. The majority of the respondents in the study area reported that their chickens are confined within the family house during night time and released for scavenging early in the morning. In contrast to this study result, Halima [4] evidenced that significant size of the rural households (51\%) of Northern Ethiopia had separate sheds for their chickens whereas, Mekonnen reported that there is no specific separate poultry houses in Dale Wereda. In some African countries, a large proportion of village poultry mortality accounted due to nocturnal predators because of lack of proper housing [9]. The appropriate housing system which is imposed by poultry management on many strains of birds has created a new challenge for breeders.

\begin{tabular}{|l|l|l|l|l|l|l|}
\hline \multirow{2}{*}{$\begin{array}{l}\text { Housing } \\
\text { system }\end{array}$} & \multicolumn{5}{|c|}{ Study districts (\%) } & \multirow{2}{*}{ Average } \\
\cline { 2 - 7 } & Meta & Deder & Gorogutu & Babbile & Jigjiga & \\
\hline Kitchen & 25 & & - & - & - & 25 \\
\hline $\begin{array}{l}\text { Separate } \\
\text { room outside } \\
\text { the house }\end{array}$ & - & 33.33 & - & - & - & 6.7 \\
\hline $\begin{array}{l}\text { Separate } \\
\text { room in the } \\
\text { house }\end{array}$ & 50 & 33.33 & 20 & 42.86 & 50 & 39.24 \\
\hline $\begin{array}{l}\text { At one corner } \\
\text { in the house }\end{array}$ & 25 & 33.33 & 40 & 14.29 & 50 & 32.52 \\
\hline $\begin{array}{l}\text { Under bed in } \\
\text { the house }\end{array}$ & - & - & - & 28.6 & - & - \\
\hline $\begin{array}{l}\text { Hand woven } \\
\text { basket }\end{array}$ & - & - & 40 & - & - & - \\
\hline $\begin{array}{l}\text { Bamboo } \\
\text { cages }\end{array}$ & - & - & - & 14.29 & - & - \\
\hline
\end{tabular}

Table 2: Respondents chicken housing systems. "-"Not implemented in the district.

Productivity of the birds: The birds have an average of 3.69 production cycles or clutch a year, and in each cycle farmers obtain 14.0 eggs per one brooding hen. The average number of eggs per clutch reported from overall study area (14.0) is similar to the national average (12) as reported by CSA. Mean annual egg production of the indigenous chickens of the districts was estimated at 51.66 eggs, the value of which is lower than those reported (55.2 eggs/year/head) from Dale wereda but higher than those reported (36-42 eggs/year/head) from Ambo. Mean annual egg production of the indigenous chickens in the study area was also higher than those reported (32 eggs/year/ hen) from Assela, indicating the improvement in egg production of the indigenous chickens. Alemu and Tadelle reported the mean annual egg production of indigenous chickens is estimated at 60 small eggs with thick shell and deep yellow yolk color. Kidane reported the average annual egg production of scavenging village indigenous chicken ranges between 30 and 60 eggs per hen at Holleta Agricultural Development Unit. The small (39\%) and medium (61\%) eggs in the study districts were the major egg sizes reported. Similarly, Brannang and Pearson reported small egg size of an average egg weight of $38 \mathrm{~g}$ for local birds at Assela livestock farm.

Functions of chickens raising: All smallholders in the study area keep chickens for multipurpose, though the function of chickens as 
source of cash income was rated to be as important as or more important than egg and meat production for home consumption. Respondents principally keep chickens to sell when need is raised as indicated in Table 3. This showing that indigenous chicken is immediate source of family income and means of saving cash. This finding is contradictory to Nigussie et al. who reported that farmers keep chickens for egg production as the principal function of home consumption and followed by the use as source of cash income and meat [5]. Similar to this study finding, in Zimbabwe chickens served as an investment and source of security for households in addition to their use as sources of meat and eggs for consumptions and of income. Although previous studies in some parts of Africa indicated that the cultural/religious role of indigenous chicken types is important, the results of the present study did not support the significance of this function.

\begin{tabular}{|l|l|l|l|l|l|l|}
\hline \multirow{2}{*}{$\begin{array}{l}\text { Function of } \\
\text { chicken }\end{array}$} & \multicolumn{5}{|c|}{ Study districts } & \multirow{2}{*}{ Average } \\
\cline { 2 - 6 } & Meta & Deder & Gorogutu & Babbile & Jigjiga & \\
\hline $\begin{array}{l}\text { Meat (Home } \\
\text { consumption) }\end{array}$ & 0.17 & 0.12 & 0.095 & 0.14 & 0.095 & 0.12 \\
\hline $\begin{array}{l}\text { Egg (Production } \\
\text { for Market) }\end{array}$ & 0.15 & 0.19 & 0.06 & 0.22 & 0.22 & 0.17 \\
\hline Source of income & 0.12 & 0.59 & 0.16 & 0.36 & 0.32 & 0.31 \\
\hline $\begin{array}{l}\text { Banking/Means } \\
\text { of saving }\end{array}$ & 0.19 & 0.22 & - & 0.42 & 0.14 & 0.19 \\
\hline
\end{tabular}

Table 3: Chicken production purpose in the study districts. Index $=$ sum of $(3 \mathrm{X}$ purpose of keeping chicken ranked first $+2 \mathrm{X}$ purpose of keeping chicken ranked second $+1 \mathrm{X}$ purpose of keeping chicken ranked third) given for each districts divided by sum of (3 X purpose of keeping chicken first $+2 \mathrm{X}$ purpose of keeping chicken ranked second $+1 \mathrm{X}$ purpose of keeping chicken ranked third) for all district

Chicken waste management's: Majority of respondents (31.74\%) used chicken manure as a fertilizer for garden vegetable production in their backwards while $30.89 \%$ of respondents do not consider chicken waste (Table 4). In this study no respondent used chicken waste for ruminant which is inconsistent to Mavimbela who reported the utilization of the waste through ruminant animals became a convenient option of disposing of the chicken waste [10].

\begin{tabular}{|l|l|l|l|l|l|l|}
\hline \multirow{2}{*}{$\begin{array}{l}\text { Ways of } \\
\text { chicken waste } \\
\text { managements }\end{array}$} & \multicolumn{5}{|c|}{ Districts (\%) } & \multirow{2}{*}{ Average } \\
\cline { 2 - 7 } & Meta & Deder & Gorogutu & Babbile & Jigjiga & \\
\hline $\begin{array}{l}\text { Used as } \\
\text { fertilizer }\end{array}$ & 33.33 & 33.33 & - & 28.56 & - & 31.74 \\
\hline Incineration & 16.67 & - & 20 & - & 25 & 20.56 \\
\hline $\begin{array}{l}\text { Throw away as } \\
\text { other waste }\end{array}$ & - & 66.67 & 60 & 42.86 & 50 & 54.8 \\
\hline Don't consider & 50 & - & 20 & 28.57 & 25 & 30.89 \\
\hline
\end{tabular}

Table 4: Respondents chicken waste managements practice. “-"Not implemented in the district.

Disease and prevention: The results of this study tend to indicate that poultry diseases are widely spread in the study districts. About $89 \%$ of the respondents confirmed that serious disease outbreak results in complete devastation of the flock. The most important disease occur in the area was named by "Fengil" (New castle disease), "Albasa" (Coccidiosis) and "Kinkin" (External parasites). Nasser et al. reported as Newcastle disease (ND) is the most important cause of economic loss in poultry production in Ethiopia. Fisseha et al. indicated Newcastle Disease (NCD) as the major and economically important constraint for village chicken production system [11]. Serkalem et al. also reported that NCD is one of the major infectious diseases affecting productivity and survival of village chicken in the central highlands of Ethiopia [12]. Aini reported diseases as the major limiting factor to rural household poultry production system in which the results of this study agreed. Moreover, none of the farmers in the study area followed regular vaccination for their chicken and majority reported the problem of veterinary services and health. The results of this study is in agreement with that of Solomon who reported that the bio-security of the backyard poultry production system is very poor and risky, since scavenging birds live together with people and other species of livestock. Poultry movement and droppings are very difficult to control and chickens freely roam in the compounds used by households and children.

\section{Farmers' selection and breeding practices}

Chicken selection criteria's: All farmers interviewed in the different districts practiced selection on breeding and replacement of female chickens based on the criteria that are set and indicated in Table 5. However; they did not practice the selection of breeding cock. Contrary to this study, Fisseha reported that, $92.2 \%$ of chicken owner farmers in Bure district have the tradition of selecting cocks for breeding stock [13]. In Kenya, Okeno et al. unlikely reported that farmers who are confining their flocks do selection of chicken for breeding. In most of study districts farmers were ranked first the egg size birds laying (0.412) and reproduction performance (Broodiness and hatchability) (0.276). The selection practices were not only limited to trait categories which influenced market price and directly or observed and/or measured on the selection candidate itself. This result is inconsistent to the report of Abdelqader et al., Nigussie et al. and Okeno et al. in which the most important traits of farmers were growth rate, disease tolerance, egg yield, body size and fertility in Jordan and Kenya [5]. The majority of the farmers in Kenya considered egg yield as the most important trait followed by mothering ability and body size. Identification of traits of economic importance is vital in the development of breeding objectives. Therefore breeding programs for improving the productivity of indigenous chicken should target these traits and consider the current and future production circumstances.

\begin{tabular}{|l|l|l|l|l|l|l|}
\hline \multirow{2}{*}{$\begin{array}{l}\text { Selection } \\
\text { criteria }\end{array}$} & \multicolumn{5}{|c|}{ Districts } & \multirow{2}{*}{ Average } \\
\cline { 2 - 7 } & Meta & Deder & Gorogutu & Babbile & Jigjiga & \\
\hline $\begin{array}{l}\text { Reproduction } \\
\text { Performance }\end{array}$ & 0.24 & 0.24 & 0.26 & 0.34 & 0.3 & 0.28 \\
\hline Size of eggs & 0.49 & 0.46 & 0.46 & 0.26 & 0.39 & 0.41 \\
\hline Size/appearance & 0.09 & 0.07 & 0.09 & 0.04 & 0.12 & 0.08 \\
\hline Broodiness & 0.02 & 0.03 & 0.06 & 0.23 & 0.02 & 0.07 \\
\hline Longevity & 0.09 & 0.16 & 0.1 & 0.1 & 0.09 & 0.11 \\
\hline Resilience & 0.06 & 0.02 & 0.02 & 0.005 & 0.03 & 0.03 \\
\hline
\end{tabular}


Comb type

\begin{tabular}{l|l|l}
0.01 & 0.01 & 0.002
\end{tabular}

0.32

0.008

0.07

Table 5: Respondents selection criteria for female chickens. Index=sum of ( $3 \mathrm{X}$ purpose of keeping chicken ranked first $+2 \mathrm{X}$ purpose of keeping chicken ranked second $+1 \mathrm{X}$ purpose of keeping chicken ranked third) given for each district divided by sum of ( $3 \mathrm{X}$ purpose of keeping chicken first $+2 \mathrm{X}$ purpose of keeping chicken ranked second $+1 \mathrm{X}$ purpose of keeping chicken ranked third) for all district.

Moreover, smallholders selected the plumage colors of the local chicken which were mixed in the study area (Table 6). Majority of the respondents $(62.38 \%)$ have no preference for plumage color while $32.62 \%$ of respondents are sensitive to plumage colors. The higher preferred plumage color in this study was black which is not easily visible to predators according to respondents. Those respondents preferring specific plumage color are like in other parts of the world, desired plumage color affecting market preferences [14]. In Northern Ethiopia both producer-sellers and intermediary traders attached the highest preference for plumage color [15]. Nigussie et al. also reported as chicken producers considered plumage colour and comb type as a selection criterion [5]. This result is in line with the report of Fisseha in which plumage color (45.4\%) and comb type (8.6\%) are some of selection criteria for breeding stock in Bure district [13]. Another study conducted in mid Rift valley of Oromia revealed that $68.0 \%$ of the farmers selected productive hens by body size for replacement.

\begin{tabular}{|l|l|l|l|l|l|l|}
\hline \multirow{2}{*}{$\begin{array}{l}\text { Plumage } \\
\text { color }\end{array}$} & \multicolumn{5}{|c|}{ Districts (\%) } & \multirow{2}{*}{ Average } \\
\cline { 2 - 7 } & Meta & Deder & Gorogutu & Babbile & Jigjiga & \\
\hline Red & 36.7 & - & - & 2.3 & 3.7 & 14.23 \\
\hline White & 17.87 & - & 10.4 & 3 & 5 & 9.07 \\
\hline Gray & 25.43 & - & - & 3.2 & 7.2 & 11.94 \\
\hline Black & - & 66.89 & - & - & 7 & 36.95 \\
\hline $\begin{array}{l}\text { No } \\
\text { preference }\end{array}$ & 20 & 33.67 & 89.6 & 91.65 & 77 & 62.38 \\
\hline
\end{tabular}

Table 6: Respondents preferences for Chicken plumage color.

Practice: Breeding practice of chickens in the study area was completely uncontrolled. Only $35 \%$ of respondents in study area reared their own cock for a breeding purpose, while other farmers exchanged or shared with their neighbors among relatives and friends within the village. All of those own their breeding cock did not give any special management and this result indicated that respondents in the study districts had no breeding experience in improving their chicken productivity. This result is in line with report of Meseret in which traditional chicken production system is characterized by lack of systematic breeding practice in Gomma district. Similarly, another study in different part of Ethiopia revealed that village chicken breeding is completely uncontrolled and replacement stock produced through natural incubation using broody hens [16].

\section{Conclusions}

The village chicken production of the study districts were characterized by traditional management which are scavenging system, no appropriate house provision, no regular vaccination programs and uncontrolled breeding practices. This lower management resulted in lower production output and the serious disease outbreaks. The preferred traits by smallholders were the egg size and reproduction performances. Majority of village chicken producers had no breeding experiences for improving their chicken productivity. Therefore; an awareness, effective promotion and advertising campaign about the chicken management, carefully handling and breeding practices of village chickens should be organized to create well-informed farmers in order to switch them from this traditional way to modern types of poultry management.

\section{References}

1. CSA (central statistical authority) (2011) Agricultural sample survey 2010/11. Volume II; statistical bulletin 505. Report on livestock and livestock characteristics, Addis Ababa, p: 190.

2. Alemu Y, Tadele D (1997) The Status of Poultry Research and Development in Ethiopia. Research Bulletin No. 4. Poultry Commodity Research Program, Debre Zeit Agricultural Research Center, Alemaya University of Agriculture, Ethiopia.

3. Hailu A, Wuletaw Z, Mazengia H (2014) Breeding practice and objective of indigenous chicken in North Wollo, Amhara regional State, Ethiopia. Int J Livest Prod 5: 15-22.

4. Halima H (2007) Phonotypic and genetic characterization of indigenous chicken populations in Northwest Ethiopia. PhD. Thesis submitted to the faculty of National and agricultural sciences, Department of Animal Wild life and Grassland Sciences University of the Free State, Bloemfontein, South Africa, p: 186.

5. Dana N, Liesbeth H, van der Waaij, Dessie T, van Arendonk JA (2010) Production objectives and trait preferences of village poultry producers of Ethiopia: implications for designing breeding schemes utilizing indigenous chicken genetic resources. Trop Anim Health Prod 42: 1519-1529.

6. Hassen H, Neser FWC, de Kock A, Marle-Köster E (2009) Study on the genetic diversity of native chickens in northwest Ethiopia using microsatellite markers. Afr J Biotechnol 8: 1347-1353.

7. Wilson RT, Traore A, Kuit HG, Slingerland M (1987) Livestock production in Central Mali: reproduction, growth and mortality of domestic fowl under traditional management. Trop Anim Health Prod 19: 229-236.

8. Abdou I, Bell JG (1992) Village poultry production in Africa, Proceedings of an International workshop held in Rabat. Morocco, pp: 6-11.

9. Dwinger RH, Bell JG, Permin A (2003) A program to improve family poultry production in Africa. In: ACIT Institute, Morocco, pp: 129-134.

10. Mavimbela DT (2000) The nutritional value of broiler litter as a feed source for sheep during periods of feed shortage. PhD Thesis, University of Pretoria.

11. Fisseha M, Abera M, Dessie T (2010) Assessment of village chicken production system and evaluation of the productive and reproductive performance of local chicken ecotype in Bure district, North West Ethiopia. Afr J Agri Res 5: 1739-1748.

12. Serkalem T, Hagos A, Zeleke A (2005) Sero-prevalence study of Newcastle disease in local chickens in central Ethiopia. Int J Appl Res Vet Med 3: 1.

13. Fisseha M, Azage T, Tadelle D (2010) Indigenous chicken production and marketing systems in Ethiopia: Characteristics and opportunities for market-oriented development. IPMS (Improving Productivity and Market Success) of Ethiopian Farmers Project Working Paper 24. Nairobi, Kenya, ILRI.

14. Jiang X (1999) Broiler breeding: breeding goals, selection schemes and the usefulness of local breeds of China, PhD Thesis, Wageningen University.

15. Aklilu HA (2007) Village poultry in Ethiopia: socio-technical analysis and learning with farmers. The Journal of Agricultural Education and Extension 15: 321-323. 
Citation: Asmelash B, Dawit M, Kebede E (2018) Characterization of Village Chicken Production and Breeding Practices of Smallholders in Eastern Ethiopia. J Vet Sci Technol 9: 507. doi:10.4172/2157-7579.1000507

16. Nigussie D (2011) Breeding programs for indigenous chicken in Ethiopia: analysis of diversity in production systems and chicken populations. $\mathrm{PhD}$ Thesis, Wageningen University, the Netherlands, p: 148. 